\title{
Growth hormone and insulin-like growth factor 1 affect the severity of Graves' disease
}

\author{
Alfredo Di Cerbo', Federica Pezzuto² and Alessandro Di Cerbo² \\ 'Endocrinology, 'Casa Sollievo della Sofferenza', IRCCS, San Giovanni Rotondo, Foggia, Italy and 2Department of \\ Medical, Oral and Biotechnological Sciences, Dental School, University 'G. d'Annunzio' of Chieti-Pescara, Chieti, Italy
}

Correspondence should be addressed to A Di Cerbo

Email

Alessandro811@hotmail.it

\section{Summary}

Graves' disease, the most common form of hyperthyroidism in iodine-replete countries, is associated with the presence of immunoglobulins G (IgGs) that are responsible for thyroid growth and hyperfunction. In this article, we report the unusual case of a patient with acromegaly and a severe form of Graves' disease. Here, we address the issue concerning the role of growth hormone (GH) and insulin-like growth factor 1 (IGF1) in influencing thyroid function. Severity of Graves' disease is exacerbated by coexistent acromegaly and both activity indexes and symptoms and signs of Graves' disease improve after the surgical remission of acromegaly. We also discuss by which signaling pathways GH and IGF1 may play an integrating role in regulating the function of the immune system in Graves' disease and synergize the stimulatory activity of Graves' IgGs.

\section{Learning points:}

- Clinical observations have demonstrated an increased prevalence of euthyroid and hyperthyroid goiters in patients with acromegaly.

- The coexistence of acromegaly and Graves' disease is a very unusual event, the prevalence being $<1 \%$.

- Previous in vitro studies have showed that IGF1 synergizes the TSH-induced thyroid cell growth-activating pathways independent of TSH/cAMP/PKA cascade.

- We report the first case of a severe form of Graves' disease associated with acromegaly and show that surgical remission of acromegaly leads to a better control of symptoms of Graves' disease.

\section{Background}

It has been widely described that hormones can affect the development, integrity and activity of the immune system (1). In general, glucocorticoids and sex steroids depress the immune response $(2,3,4)$, whereas $\mathrm{GH}$, prolactin and IGF1 are considered growth and differentiation factors for lymphoid cells and increase the immune response $(5,6,7,8)$. The function of the immune system can be influenced at several levels, such as the interaction between antigen-presenting cells (APCs) and lymphocytes, mobility, migration and homing of immune cells and production of cytokines (1). Moreover, some hormones such as glucocorticoids have been shown to affect the expression of major histocompatibility complex (MHC) molecules in APCs (9), the relationship between helper and cytotoxic T lymphocytes (10), and the interaction between idiotypes and anti-idiotypes (1).

Graves' disease, the most common form of thyrotoxicosis, has been associated with the presence of immunoglobulins $\mathrm{G}$ (IgGs) that are able to bind the TSH receptor (TSHR), compete with TSH and stimulate thyroid hormone synthesis and thyroid growth by increasing the cellular levels of cyclic AMP (cAMP) $(11,12,13)$ as well as other second messengers, such as arachidonic acid and calcium $(14,15,16)$. What is not yet known is whether 
endocrine factors, in particular GH, intervene in regulating the production and synergizing the stimulatory activity of IgGs responsible for the development and maintenance of Graves' disease.

In this article, we report the unusual case of a patient suffering from Graves' disease and coexisting acromegaly and show that activity indexes of Graves' disease are substantially reduced in parallel to the surgical remission of acromegaly. We also discuss by which signaling pathways GH and IGF1 may play an integrating role in regulating the function of the immune system in Graves' disease and synergize the stimulatory activity of Graves' IgGs.

\section{Case presentation}

A 50-year-old woman was referred to us because of palpitations, tremors, excessive sweating, acral enlargement, backache and joint pains. Physical examination revealed coarsening of facial features, mild tachycardia, diffuse thyroid enlargement, accompanied by a bruit and a firm, bilateral thickening over the legs suggesting pretibial myxedema in the absence of ophthalmopathy.

\section{Investigation}

Thyroid ultrasound showed an enlarged, diffusely hypoechoic and hypervascular thyroid gland. Symptoms and signs suggested the coexistence of Graves' disease and acromegaly. Both diagnoses were confirmed by elevated free T3 (44.5 pmol/L and normal: $4.6-9.2 \mathrm{pmol} / \mathrm{L})$, free T4 (77.6 pmol/L and normal: 9-24.5 pmol/L), GH $(26.0 \mu \mathrm{g} / \mathrm{L}$ and normal: $0.1-2.0 \mu \mathrm{g} / \mathrm{L})$, IGF1 $(615 \mu \mathrm{g} / \mathrm{L}$ and normal: $90-260 \mu \mathrm{g} / \mathrm{L}$ ) levels, undetectable TSH serum concentration and lack of suppression of GH to $<1 \mu \mathrm{g} / \mathrm{L}$ following hyperglycemia during an oral glucose load. TSH binding inhibiting IgGs (TBII) concentration was measured by a commercially available radioreceptor assay. Stimulating TSHR antibodies (TSHRSAb) were also evaluated measuring cAMP generation induced by IgGs in FRTL5 thyroid cells as previously described (14). Both TBII and TSHRSAb were found extremely elevated $(1758 \mathrm{U} / \mathrm{L}$, normal: $0-10 \mathrm{U} / \mathrm{L}$, and $1120 \%$ of the basal, normal: 100 $140 \%$ of the basal, respectively). Due to TBII values above the range of calibration curve, samples were opportunely diluted in zero standard. Magnetic resonance imaging (MRI) of the pituitary revealed the presence of a $0.8 \mathrm{~cm}$ diameter microadenoma in the right side of the gland causing a moderate leftward shift of the pituitary stalk.

\section{Treatment}

Since the patient refused radioiodine therapy and thyroidectomy, treatment with methimazole was initiated with a $30 \mathrm{mg}$ daily dose gradually tapered according to the degree of thyroid dysfunction. However, due to progressive increase in TBII/TSHRSAb concentrations, both clinical conditions and serum FT3 and FT4 levels did not allow to reduce the dose of methimazole below $20 \mathrm{mg}$ per day over the next several months (Fig. 1). Due to the severe symptoms and signs of GH/IGF1 excess, treatment with octreotide long-acting release (LAR) was initiated at the monthly dose of $20 \mathrm{mg}$. After a few months the patient underwent transsphenoidal microsurgery (TSMS). The presence of a somatotroph adenoma was pathologically confirmed, and adenoma cells were positive for $\mathrm{GH}$, not for other pituitary hormones, at immunocytochemistry. After surgical therapy, the acromegaly was considered 'in surgical remission' on a clinical and biochemical basis, i.e. remission of symptoms with a normal residual anterior and posterior pituitary function, normal pattern of pulsatile GH release (mean daily value: $1.5 \mu \mathrm{g} / \mathrm{L}$ ), normal GH response to oral glucose (nadir: $0.2 \mu \mathrm{g} / \mathrm{L}$ ) and normal IGF1 serum concentration $(220 \mu \mathrm{g} / \mathrm{L})$.

\section{Outcome and follow-up}

Postoperative MRI performed six months after surgery showed normal residual adenohypophysis, a normal neurohypophyseal bright spot and no residual or recurrent tumor, findings correlating with the functional preservation of the pituitary gland. Unexpectedly,

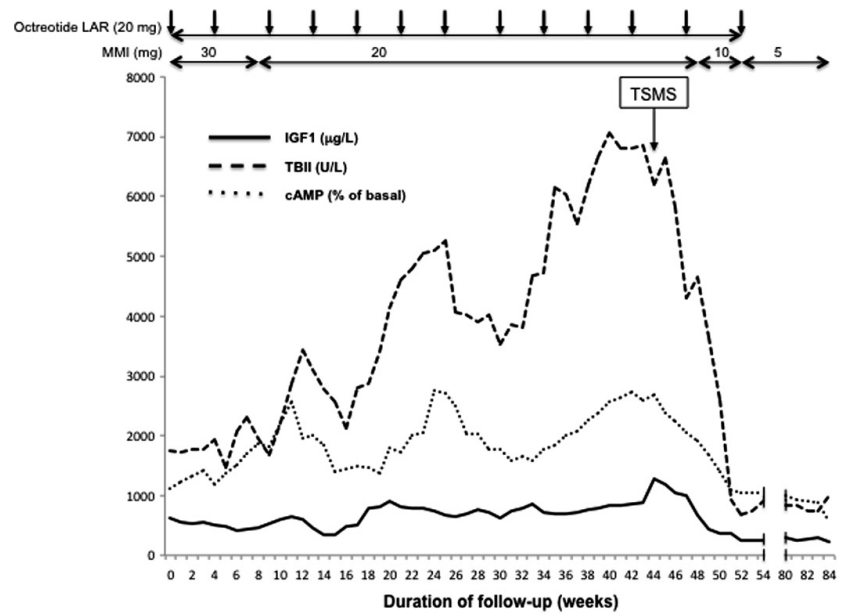

Figure 1

Serum concentrations of IGF1 and TBII and CAMP values over the course of follow-up. MMI, methimazole; TSMS, transsphenoidal microsurgery. 
the patient also showed a significant improvement of all indexes of Graves' disease activity. In particular, a sharp and significant reduction in TBII/TSHRSAb concentrations was demonstrated in several controls and was accompanied by a concurrent reduction in thyroid volume (Figs 1 and 2) and a better control of the disease symptoms. At that time only it was possible to reduce the dose of methimazole to $5 \mathrm{mg}$ per day.

Due to the possible coexistence of TSHR-blocking antibodies (TSHRBAb), blocking activity, defined as percent inhibition of TSH-dependent cAMP accumulation, was measured, calculated with the following formula: $\{1-[$ cAMP accumulation in the presence of TSH $(1 \mathrm{IU} / \mathrm{mL})$ and patient IgG/cAMP accumulation in the presence of TSH and normal $\operatorname{IgG}]\} \times 100$, and found negative in all samples (data not shown).

\section{Statistical analysis}

Data were analyzed using GraphPad Prism 6 software (GraphPad Software Inc., La Jolla, CA, USA). All data are presented as the means \pm S.E.M. and were first checked for normality using the D'Agostino-Pearson normality test. A two-sample unpaired Student's $t$-test was applied to analyze the differences in thyroid volumes, TBII, cyclic AMP and IGF1 before and after TSMS. A ${ }^{*} P<0.05$ was considered significant.
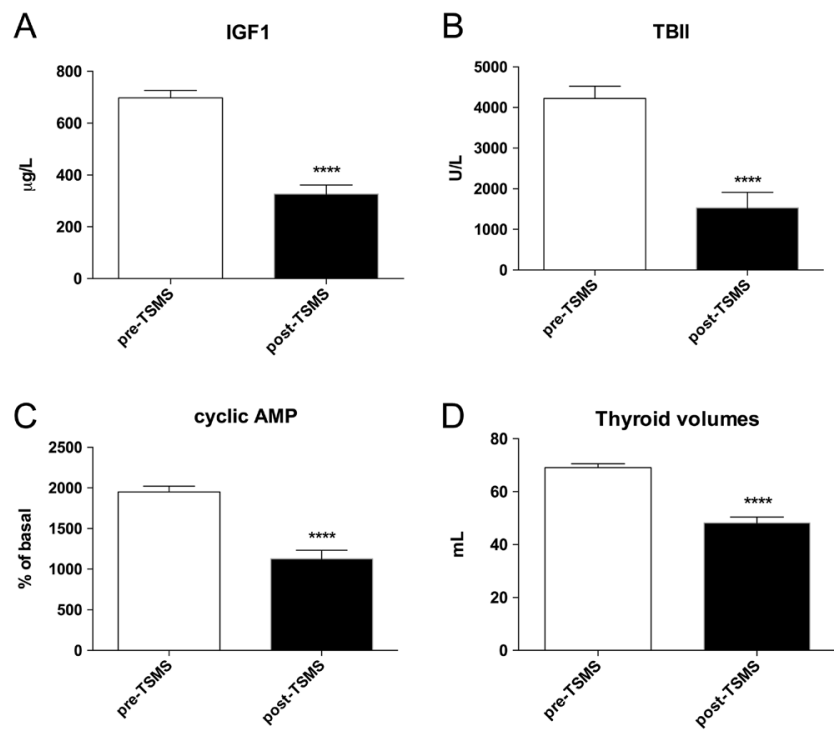

Figure 2

(A) IGF1, (B) TBII concentrations, (C) CAMP production and (D) thyroid volumes before and after transsphenoidal microsurgery (TSMS). Results are shown as means \pm S.E.M. of pre- $(n=44)$ and post-TSMS $(n=40)$ determinations, $* * * * P<0.0001$.

\section{Discussion}

The regulation of thyroid function and growth has been well characterized and appears to be related to stimuli acting through the G protein-coupled receptor (GPCR) TSHR, like TSH and Graves' IgGs, and the tyrosine kinase (TK) IGF1 receptor (IGF1R), like IGF1 (17).

Three types of TSHR antibodies have been described in patients with autoimmune thyroid disease: stimulating (TSHRSAb), blocking (TSHRBAb) and cleavage antibodies. The biological activity varies among the different classes of these autoantibodies. The proportion of these differing antibodies contributes to the different phenotypes of Graves' disease (18). These autoantibodies activate distinct $G$ proteins and signaling pathways. Thus, TSHRSAb recognize epitopes in extracellular domain of TSHR, activate Gas/AC/PKA/CREB-Erk, $\mathrm{G} \alpha \mathrm{q} / \mathrm{PLC} / \mathrm{PI}_{3} \mathrm{~K} / \mathrm{Akt}$ and $\mathrm{G} \alpha \mathrm{q} / \mathrm{PKC} / \mathrm{Erk} / \mathrm{Elk}$ pathways and are responsible for thyroid cell proliferation and function and survival (Fig. 3).

TSHR-blocking and cleavage antibodies bind to separate TSHR epitopes and induce different signaling cascades with a recognized weak agonist activity (19).

The relationship between thyroid function and GH/IGF1 axis has been the subject of a number of reports. However, previous studies on hyper- or hypothyroid acromegalic patients have been almost exclusively focused on the relation between thyroid status and GH secretion. Thus, the release of GH has been shown to be blunted in hypothyroidism (20), whereas a normal $(20,21,22)$, decreased $(23,24)$ or increased $(25) \mathrm{GH}$ response to provocative stimuli have been reported in hyperthyroidism. Conversely, elevated serum levels of GH are known to be a cause of goiter development $(26,27$, 28,29 ). The stimulation of proliferation and differentiation of thyroid cells occurs via the activation of IGF1R that are expressed on the thyroid cell membrane $(30,31$, $32,33)$. The appearance of goiter and the coexistence of frank hyperthyroidism have been reported in $18-50 \%$ and $5 \%$ of acromegalic patients, respectively $(28,34,35)$, most of these patients being suffering from non-autoimmune forms of hyperthyroidism (36). Moreover, thyroid volume and nodularity correlate with disease duration (37).

In this article, we show that GH and IGF1 play a role in influencing the production of autoantibodies directed against the TSHR, exacerbating TSHR-induced Graves' thyrotoxicosis.

By what mechanism GH and IGF1 may potentiate the action of TSHRSAb and influence the severity of Graves' disease? 


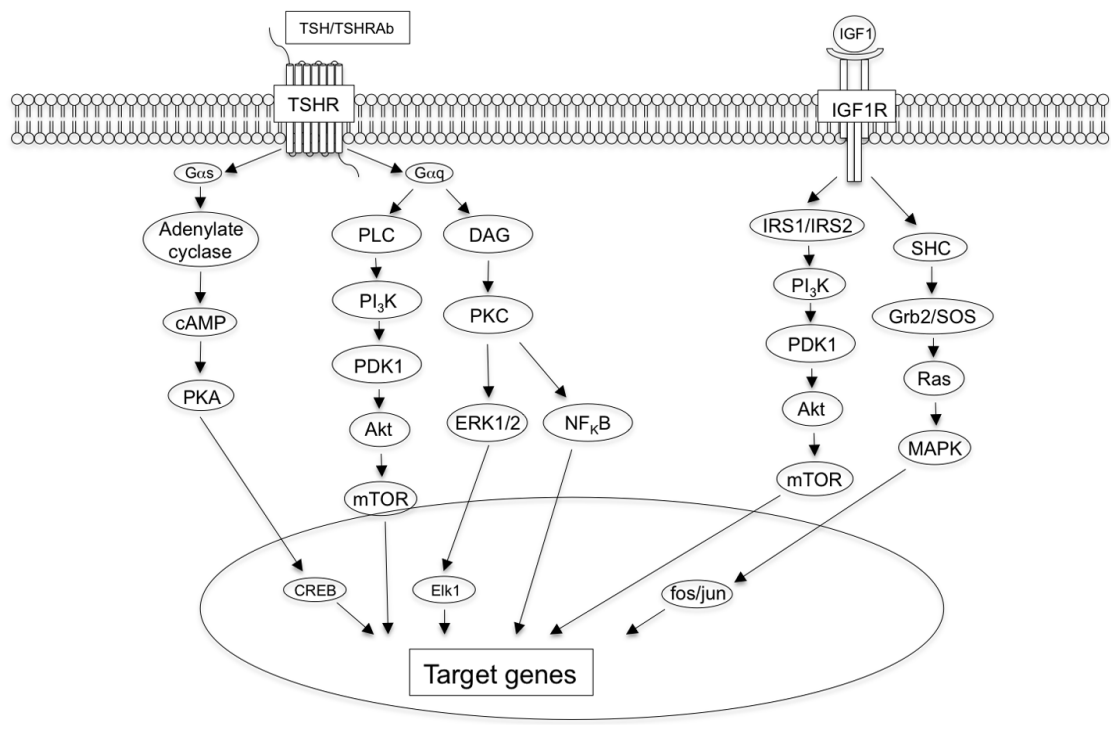

Figure 3

Diagrammatic representation of the TSH and IGF1 signaling pathways, which are demonstrated to be involved in the regulation of function, growth and survival of follicular cell. Note that $\mathrm{PI}_{3} \mathrm{~K} / \mathrm{PDK} 1 /$ Akt/mTOR cascades are common to TSHR and IGF1R signaling pathways.
$\mathrm{GH}$ is involved in immunoregulation acting upon a cell by binding its receptor at the cell membrane. The $\mathrm{GH}$ receptor (GHR), which is copiously expressed on B lymphocytes, less in $\mathrm{T}$ lymphocytes $(7,38)$, belongs to the cytokine receptor superfamily. GHR is not a tyrosine kinase, but associates with the nonreceptor ubiquitous Janus activating kinase (JAK) 2 that transduces GH-mediated signals inducing phosphorylation of transcription factor substrates, including members of the signal transducer and activator of transcription (STAT) family, mainly STAT5b that is regarded as the major effector of GH action $(39,40)$. Besides STAT5b, JAK2 also phosphorylates members of the (i) Shc/Grb2-SOS/Ras/Raf/ MAPK/Erk and (ii) IRS/PI ${ }_{3} \mathrm{~K} / \mathrm{PDK} 1 /$ Akt pathways (Fig. 4) that cross-talk with STAT5b to influence gene expression and cell proliferation (39).

Evidence from previous studies has demonstrated that GH enhances proliferation of T cells (41) and human B cell immunoglobulin production and proliferation in vitro (42). Moreover, the $\mathrm{GH}$ effect is not mediated by IGF1 (43). Thus, GH might per se stimulate the TSHRSAb production by B lymphocytes.

IGF1 affects the development and function of both $\mathrm{T}$ and $\mathrm{B}$ lymphocytes and thyrocytes by binding the tyrosine kinase IGF1R. A number of studies have clarified the influence exerted by the activation of the IGF1/IGF1R signaling pathway on many aspects of immune function (44). Briefly, activation of IGF1R results in the recruitment and phosphorylation of multiple adaptor proteins and activation of multiple downstream pathways including (i) IRS1/IRS2 activating $\mathrm{PI}_{3} \mathrm{~K} / \mathrm{PDK} 1 /$ Akt pathway; (ii) Shc linked to the Ras/MAPK/fos-jun pathway by recruitment of Grb2/SOS complex and (iii) the JAK/STAT pathway
(Fig. 3). Thus, IGF1 promotes maturation and proliferation, stimulates glucose metabolism and inflammatory cytokine production in $\mathrm{T}$ lymphocytes and maintains $\mathrm{T}$ cell survival inhibiting apoptosis gene expression $(44,45)$. Moreover, it plays a key role in B cell differentiation (46).

IGF1 as well as other members of IGF family cooperate with TSH in regulating thyroid function and growth. The relationship between IGF1R and TSHR has been demonstrated in pioneering reports by Tramontano and coworkers showing a synergistic and dose-dependent effect of IGF1, TSH and Graves' immunoglobulins on DNA synthesis and thyroid cell proliferation $(47,48)$. Moreover, other groups have showed that GPCR/cAMP/ PKA signaling activates $\mathrm{PI}_{3} \mathrm{~K} /$ Akt pathway, confirming that Ras, Akt and $\mathrm{PI}_{3} \mathrm{~K}$, downstream effectors of the IGF1R

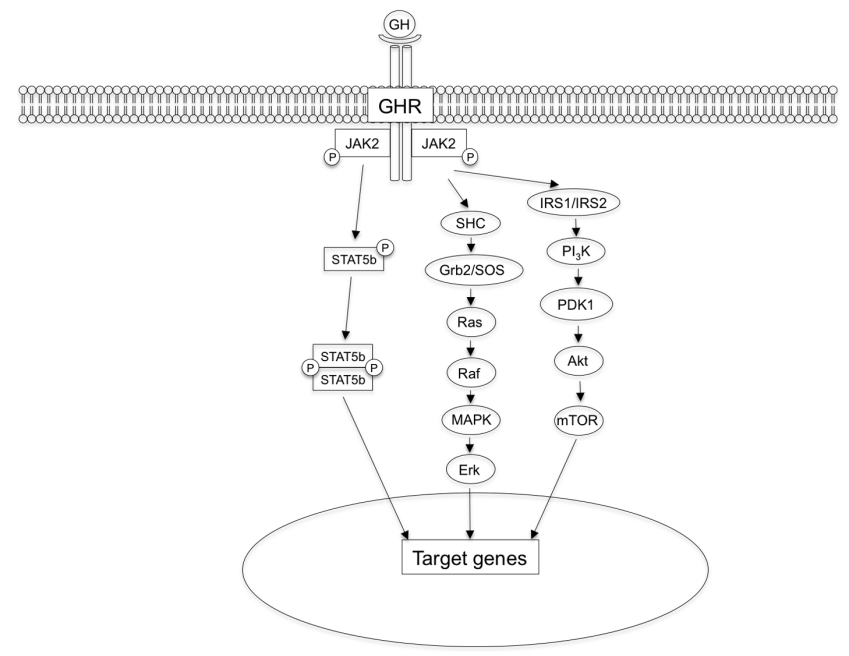

Figure 4

The growth hormone signaling pathways in B cells. 
signaling, are also involved in TSH/cAMP-induced thyroid cell proliferation $(49,50,51)$.

Together, all the above-mentioned data show that thyroid cell function and proliferation is regulated by the activation of the G protein-coupled TSHR as well as the tyrosine kinase IGF1R and may represent the molecular basis that substantiates our assumption that elevated concentrations of GH and IGF1 play a role in determining the severity of hyperthyroidism in this patient. GH and IGF1 may act by multiple mechanisms: (i) by stimulating $\mathrm{T}$ cell proliferation and inflammatory cytokine production by $\mathrm{T}$ cells infiltrating the thyroid; (ii) by stimulating $\mathrm{B}$ cell immunoglobulin production and proliferation and (iii) by promoting post receptor pathways directly in thyroid cells, how it more frequently occurs in nonautoimmune thyroid growth. Nevertheless, some questions may arise. First, the alternate circumstance that TSH simultaneously secreted by the pituitary adenoma could have occurred. However, the negativity for TSH at immunocytochemistry, the undetectable levels of TSH and the positivity of TBII and TSHRSAb exclude the possibility that this patient was suffering from a non-autoimmune form of hyperthyroidism due to the production of TSH by the pituitary adenoma. Second, theoretically, the concurrent presence of TSHRBAb might have played a role in reducing the severity of Graves' disease neutralizing the activity of TSHRSAb. Actually, this possibility has been excluded based on the negativity of TSHRBAb assay throughout the entire follow-up.

Similar to patients with other autoimmune diseases, Graves' patients may enter remission spontaneously or after a course of medical therapy. Thionamide drugs (methimazole or its pro-drug carbimazole and propylthiouracil), which are commonly used in the treatment of Graves' disease, have been suggested to have important direct immunosuppressive effects such as inhibition of thyroid autoantibody production $(52,53)$, increase of activated and total circulating $\mathrm{CD}^{+}$cells (54) and reduced numbers of intrathyroidal and thymic lymphocytes (55). However, over the years, clinical studies of Graves' disease patients have questioned the immunosuppressive hypothesis on the basis of the following findings: (i) the fall in TSHR antibodies is seen independently of the type of drug (methimazole or perchlorate) (56); (ii) the fall in TSHR antibodies is similar during therapy with a thionamide drug and after surgical therapy (57); (iii) the fall in TSHR antibodies as well as the risk of relapse of Graves' disease is seen independently of neither the dose of thionamide nor the levothyroxine replacement (58). Thus, it could be argued that a simultaneous and coincidental improvement of acromegaly and Graves' disease might be occurred in this patient. Indeed, regardless of the debate about the possible immunosuppressive effect of thionamide drug, our data clearly show that the decrease of autoantibody titers and the amelioration of clinical condition of our patient seem clearly to be related to surgical remission of acromegaly (Fig. 1).

In conclusion, the present case illustrates the uncommon occurrence of Graves' disease and acromegaly. Biochemical data clearly showed that hyperthyroidism in this patient was due to a severe form of Graves' disease. The activity of Graves' disease, as evaluated by the ability of patient's IgG to block TSH binding and induce the production of cyclic AMP, goes parallel to the activity of acromegaly, based on abnormal concentration of IGF1 (as shown in Fig. 1), confirming the assumption that GH/ IGF1 axis may play an important role in maintaining the activity and exacerbating the clinical course of Graves' disease. Thus, this patient might be considered an in vivo model for studying the action of GH/IGF1 axis on immune system in Graves' disease patients.

Declaration of interest

The authors declare that there is no conflict of interest that could be perceived as prejudicing the impartiality of the research reported.

\section{Funding}

This research did not receive any specific grant from any funding agency in the public, commercial or not-for-profit sector.

\section{Patient consent}

The authors have obtained informed consent from the patient for publication, which is enclosed along with manuscript.

\section{Author contribution statement}

A D C, physician of the patient, performed both physical and instrumental examinations and wrote the paper. A D C performed the statistical analysis and performed data interpretation. $\mathrm{F} P$ participated in manuscript drafting and discussed the results. All authors read and approved the final manuscript.

\section{References}

1 Besedovsky HO \& del Rey A 1996 Immune-neuro-endocrine interactions: facts and hypotheses. Endocrine Reviews 17 64-102. (doi:10.1210/edrv-17-1-64)

2 Munck A \& Guyre P 1991 Glucocorticoids and immune function. In Psychoneuroimmunology, edn 2nd, pp 447-513. Eds R Ader, D Felten \& N Cohen. New York: Academic Press, Elsevier Science. 
3 Munck A, Guyre PM \& Holbrook NJ 1984 Physiological functions of glucocorticoids in stress and their relation to pharmacological actions. Endocrine Reviews 5 25-44. (doi:10.1210/edrv-5-1-25)

4 Bateman A, Singh A, Kral T \& Solomon S 1989 The immunehypothalamic-pituitary-adrenal axis. Endocrine Reviews 10 92-112. (doi:10.1210/edrv-10-1-92)

5 Weigent DA 1996 Immunoregulatory properties of growth hormone and prolactin. Pharmacology and Therapeutics 69 237-257. (doi:10.1016/0163-7258(96)00001-0)

6 Velkeniers B, Dogusan Z, Naessens F, Hooghe R \& Hooghe-Peters EL 1998 Prolactin, growth hormone and the immune system in humans Cellular and Molecular Life Sciences 54 1102-1108. (doi:10.1007/ s000180050239)

7 Clark R 1997 The somatogenic hormones and insulin-like growth factor-1: stimulators of lymphopoiesis and immune function. Endocrine Reviews 18 157-179. (doi:10.1210/edrv.18.2.0296)

8 Kelley K 1991 Growth hormone in immunobiology. In Psychoneuroimmunology, edn 2nd, pp 377-402. Eds R Ader, D Felten \& N Cohen. New York: Academic Press, Elsevier Science.

9 Rhodes J, Ivanyi J \& Cozens P 1986 Antigen presentation by human monocytes: effects of modifying major histocompatibility complex class II antigen expression and interleukin 1 production by using recombinant interferons and corticosteroids. European Journal of Immunology 16 370-375. (doi:10.1002/eji.1830160410)

10 Fauci AS \& Dale DC 1974 The effect of in vivo hydrocortisone on subpopulations of human lymphocytes. Journal of Clinical Investigation 53 240-246. (doi:10.1172/JCI107544)

11 Kohn LD, Shimura H, Shimura Y, Hidaka A, Giuliani C, Napolitano G, Ohmori M, Laglia G \& Saji M 1995 The thyrotropin receptor. In Vitamins and Hormones, pp 287-384. Ed G Litwack. New York: Academic Press, 1995. (doi:10.1016/S0083-6729(08)60658-5)

12 Zakarija M \& McKenzie JM 1987 The spectrum and significance of autoantibodies reacting with the thyrotropin receptor. Endocrinology Metabolism Clinics of North America 16 343-363.

13 Rees Smith B, McLachlan SM \& Furmaniak J 1988 Autoantibodies to the thyrotropin receptor. Endocrine Reviews 9 106-121. (doi:10.1210/ edrv-9-1-106)

14 Di Cerbo A, Di Girolamo M, Guardabasso V, De Filippis V \& Corda D 1992 Immunoglobulins from Graves' patients stimulate phospholipase-A2 in FRTL5 thyroid cells. Journal of Clinical Endocrinology and Metabolism 74 585-592. (doi:10.1210/ jcem.74.3.1310998)

15 Kosugi S, Okajima F, Ban T, Hidaka A, Shenker A \& Kohn LD 1993 Substitutions of different regions of the third cytoplasmic loop of the thyrotropin (TSH) receptor have selective effects on constitutive, TSH-, and TSH receptor autoantibody-stimulated phosphoinositide and 3',5'-cyclic adenosine monophosphate signal generation. Molecular Endocrinology 7 1009-1020. (doi:10.1210/ mend.7.8.7901757)

16 Atwa MA, Smallridge RC, Burch HB, Gist ID, Lu R, Abo-Hashem EM, el-Kannishy MH \& Burman KD 1996 Immunoglobulins from Graves' disease patients stimulate phospholipase A2 and C systems in FRTL-5 and human thyroid cells. European Journal of Endocrinology $\mathbf{1 3 5}$ 322-327. (doi:10.1530/eje.0.1350322)

17 Dumont JE, Lamy F, Roger P \& Maenhaut C 1992 Physiological and pathological regulation of thyroid cell proliferation and differentiation by thyrotropin and other factors. Physiological Reviews 72 667-697.

18 Morshed SA \& Davies TF 2015 Graves' disease mechanisms: the role of stimulating, blocking, and cleavage region TSH receptor antibodies. Hormone and Metabolic Research 47 727-734. (doi:10.1055/ s-0035-1559633)

19 Morshed SA, Latif R \& Davies TF 2009 Characterization of thyrotropin receptor antibody-induced signaling cascades. Endocrinology 150 519-529. (doi:10.1210/en.2008-0878)
20 Katz HP, Youlton R, Kaplan SL \& Grumbach MM 1969 Growth and growth hormone. 3. Growth hormone release in children with primary hypothyroidism and thyrotoxicosis. Journal of Clinical Endocrinology and Metabolism 29 346-351. (doi:10.1210/ jcem-29-3-346)

21 Rosenfeld PS, Wool MS \& Danforth E Jr 1969 Growth hormone response to insulin-induced hypoglycemia in thyrotoxicosis. Journal of Clinical Endocrinology and Metabolism 29 777-780. (doi:10.1210/ jcem-29-6-777)

22 Strauch G, Modigliani E \& Bricaire H 1969 Growth hormone response to arginine in normal and hyperthyroid females under propanolol. Journal of Clinical Endocrinology and Metabolism 29 606-608. (doi:10.1210/jcem-29-4-606)

23 Giustina G, Reschini E, Valentini F \& Cantalamessa L 1971 Growth hormone and cortisol responses to insulin-induced hypoglycemia in thyrotoxicosis. Journal of Clinical Endocrinology and Metabolism $\mathbf{3 2}$ 571-574. (doi:10.1210/jcem-32-4-571)

24 Finkelstein JW, Boyar RM \& Hellman L 1974 Growth hormone secretion in hyperthyroidism. Journal of Clinical Endocrinology and Metabolism 38 634-637. (doi:10.1210/jcem-38-4-634)

25 Shimatsu A, Murabe H, Sasaki S, Hattori N, Tanoh T \& Imura H 1990 Secretory dynamics of growth hormone in an acromegalic patient associated with Graves' disease. Journal of Clinical Endocrinology and Metabolism 71 1059-1063. (doi:10.1210/jcem-71-4-1059)

26 Davidoff LM 1926 Studies in acromegaly III. The anamnesis and symptomatology in one hundred cases. Endocrinology 10 461-483. (doi:10.1210/endo-10-5-461)

27 Austin C \& Davies A 1941 The thyroid gland in 166 case of acromegaly. Journal of Clinical Endocrinology 1 445-449. (doi:10.1210/ jcem-1-5-445)

28 Kasagi K, Shimatsu A, Miyamoto S, Misaki T, Sakahara H \& Konishi J 1999 Goiter associated with acromegaly: sonographic and scintigraphic findings of the thyroid gland. Thyroid 9 791-796. (doi:10.1089/thy.1999.9.791)

29 Curto L, Giovinazzo S, Alibrandi A, Campenni A, Trimarchi F, Cannavo S \& Ruggeri RM 2015 Effects of GH replacement therapy on thyroid volume and nodule development in GH deficient adults: a retrospective cohort study. European Journal of Endocrinology 172 543-552. (doi:10.1530/EJE-14-0966)

30 van der Laan BF, Freeman JL \& Asa SL 1995 Expression of growth factors and growth factor receptors in normal and tumorous human thyroid tissues. Thyroid 5 67-73. (doi:10.1089/thy.1995.5.67)

31 Malaguarnera R, Frasca F, Garozzo A, Giani F, Pandini G, Vella V, Vigneri R \& Belfiore A 2011 Insulin receptor isoforms and insulinlike growth factor receptor in human follicular cell precursors from papillary thyroid cancer and normal thyroid. Journal of Clinical Endocrinology and Metabolism 96 766-774. (doi:10.1210/jc.2010-1255)

32 Eggo MC, Bachrach LK \& Burrow GN 1990 Interaction of $\mathrm{TSH}$, insulin and insulin-like growth factors in regulating thyroid growth and function. Growth Factors 2 99-109. (doi:10.3109/08977199009071497)

33 Isozaki O, Santisteban P, Chan J, Grollman E \& Kohn L 1987 Insulin and insulin-like growth factor-I (IGF-I) regulate differentiation as well as growth in FRTL-5 cells. Acta Endocrinologica: Supplementum 281 288-292. (doi:10.1530/acta.0.114S288)

34 Wuster C, Steger G, Schmelzle A, Gottswinter J, Minne HW \& Ziegler R 1991 Increased incidence of euthyroid and hyperthyroid goiters independently of thyrotropin in patients with acromegaly. Hormone and Metabolic Research 23 131-134. (doi:10.1055/s-2007-1003632)

35 Seif FJ, Scherbaum WA, Knisel W, Feine U \& Meinke J 1983 Struma Thyreoidale Autonomie und Hyperthyreose bei Akromegalie. Stuttgart, New York: Thieme Verlag.

36 Meng W, Ventz M, Streckenbach B \& Hampel R 1985 Kombination von Akromegalie und Autonomen Adenom der Schilddrüse: Zufall, STH-Effekt oder form der MEA? Stuttgart/New York: Georg Thieme Verlag. 
37 Dogan S, Atmaca A, Dagdelen S, Erbas B \& Erbas T 2014 Evaluation of thyroid diseases and differentiated thyroid cancer in acromegalic patients. Endocrine 45 114-121. (doi:10.1007/s12020-013-9981-3)

38 Rapaport R, Sills IN, Green L, Barrett P, Labus J, Skuza KA, Chartoff A, Goode L, Stene M \& Petersen BH 1995 Detection of human growth hormone receptors on IM-9 cells and peripheral blood mononuclear cell subsets by flow cytometry: correlation with growth hormonebinding protein levels. Journal of Clinical Endocrinology and Metabolism 80 2612-2619. (doi:10.1210/jcem.80.9.7673403)

39 Chia DJ 2014 Minireview: mechanisms of growth hormone-mediated gene regulation. Molecular Endocrinology 28 1012-1025. (doi:10.1210/ me.2014-1099)

40 Waters MJ \& Brooks AJ 2015 JAK2 activation by growth hormone and other cytokines. Biochemical Journal 466 1-11. (doi:10.1042/ BJ20141293)

41 Mercola KE, Cline MJ \& Golde DW 1981 Growth hormone stimulation of normal and leukemic human T-lymphocyte proliferation in vitro. Blood 58 337-340. (doi:10.0000/www.blood journal.org/content/58/2/337)

42 Yoshida A, Ishioka C, Kimata H \& Mikawa H 1992 Recombinant human growth hormone stimulates B cell immunoglobulin synthesis and proliferation in serum-free medium. Acta Endocrinologica 126 524-529. (doi:10.1530/acta.0.1260524)

43 Kimata H \& Yoshida A 1994 Effect of growth hormone and insulinlike growth factor-I on immunoglobulin production by and growth of human B cells. Journal of Clinical Endocrinology and Metabolism 78 635-641. (doi:10.1210/jcem.78.3.8126135)

44 Smith TJ 2010 Insulin-like growth factor-I regulation of immune function: a potential therapeutic target in autoimmune diseases? Pharmacological Reviews 62 199-236. (doi:10.1124/pr.109.002469)

45 Smith TJ, Hegedus L \& Douglas RS 2012 Role of insulin-like growth factor-1 (IGF-1) pathway in the pathogenesis of Graves' orbitopathy. Best Practice and Research: Clinical Endocrinology and Metabolism 26 291-302. (doi:10.1016/j.beem.2011.10.002)

46 Taguchi T, Takenouchi H, Matsui J, Tang WR, Itagaki M, Shiozawa Y, Suzuki K, Sakaguchi S, Ktagiri YU, Takahashi T, et al. 1992 Insulinlike growth factor-I regulates pro-B cell differentiation. Blood $\mathbf{8 0}$ 1207-1212.

47 Tramontano D, Cushing GW, Moses AC \& Ingbar SH 1986 Insulin-like growth factor-I stimulates the growth of rat thyroid cells in culture and synergizes the stimulation of DNA synthesis induced by TSH and Graves'-IgG. Endocrinology 119 940-942. (doi:10.1210/endo119-2-940)

48 Tramontano D, Moses AC, Veneziani BM \& Ingbar SH 1988 Adenosine $3^{\prime}, 5^{\prime}$-monophosphate mediates both the mitogenic effect of thyrotropin and its ability to amplify the response to insulinlike growth factor I in FRTL5 cells. Endocrinology 122 127-132. (doi:10.1210/endo-122-1-127)

49 Cass LA \& Meinkoth JL 2000 Ras signaling through PI3K confers hormone-independent proliferation that is compatible with differentiation. Oncogene 19 924-932. (doi:10.1038/ sj.onc.1203393)

50 Ciullo I, Diez-Roux G, Di Domenico M, Migliaccio A \& Avvedimento EV 2001 cAMP signaling selectively influences Ras effectors pathways. Oncogene 20 1186-1192. (doi:10.1038/sj.onc.1204219)

51 De Gregorio G, Coppa A, Cosentino C, Ucci S, Messina S, Nicolussi A, D'Inzeo S, Di Pardo A, Avvedimento EV \& Porcellini A 2007 The p85 regulatory subunit of PI3K mediates TSH-cAMP-PKA growth and survival signals. Oncogene 26 2039-2047. (doi:10.1038/ sj.onc.1210011)

52 McGregor AM, Petersen MM, McLachlan SM, Rooke P, Smith BR \& Hall R 1980 Carbimazole and the autoimmune response in Graves' disease. New England Journal of Medicine 303 302-307. (doi:10.1056/ NEJM198008073030603)

53 Weiss I \& Davies TF 1981 Inhibition of immunoglobulin-secreting cells by antithyroid drugs. Journal of Clinical Endocrinology and Metabolism 53 1223-1228. (doi:10.1210/jcem-53-6-1223)

54 Ludgate ME, McGregor AM, Weetman AP, Ratanachaiyavong S, Lazarus JH, Hall R \& Middleton GW 1984 Analysis of T cell subsets in Graves' disease: alterations associated with carbimazole. BMJ $\mathbf{2 8 8}$ 526-530. (doi:10.1136/bmj.288.6416.526)

55 Beck JS, Young RJ, Simpson JG, Gray ES, Nicol AG, Pegg CA \& Michie W 1973 Lymphoid tissue in the thyroid gland and thymus of patients with primary thyrotoxicosis. British Journal of Surgery $\mathbf{6 0}$ 769-771. (doi:10.1002/bjs.1800601005)

56 Wenzel KW \& Lente JR 1984 Similar effects of thionamide drugs and perchlorate on thyroid-stimulating immunoglobulins in Graves' disease: evidence against an immunosuppressive action of thionamide drugs. Journal of Clinical Endocrinology and Metabolism $\mathbf{5 8}$ 62-69. (doi:10.1210/jcem-58-1-62)

57 Torring O, Tallstedt L, Wallin G, Lundell G, Ljunggren JG, Taube A, Saaf M \& Hamberger B 1996 Graves' hyperthyroidism: treatment with antithyroid drugs, surgery, or radioiodine- a prospective, randomized study. Thyroid Study Group. Journal of Clinical Endocrinology and Metabolism 81 2986-2993. (doi:10.1210/ jcem.81.8.8768863)

58 Abraham P, Avenell A, Park CM, Watson WA \& Bevan JS 2005 A systematic review of drug therapy for Graves' hyperthyroidism. European Journal of Endocrinology 153 489-498. (doi:10.1530/ eje.1.01993)

Received in final form 3 May 2017

Accepted 10 May 2017 